\title{
Access to the Unified Health System in the perspective of male homosexuals
}

\author{
O acesso ao Sistema Único de Saúde na percepção de homossexuais masculinos \\ Acceso al Sistema de Salud Unificado en la perspectiva de los homosexuales masculinos
}

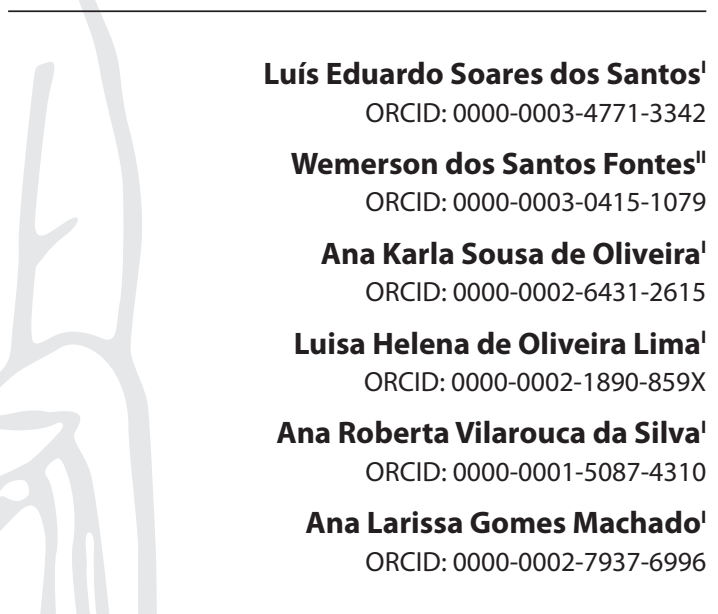

'Universidade Federal do Piauí. Picos, Piauí, Brazil. "Hospital Regional Deolindo Couto. Oeiras, Piauí, Brazil

How to cite this article:

Santos LES, Fontes WS, Oliveira AKS, Lima LHO, Silva ARV, Machado ALG. Access to the Unified Health System in the perspective of male homosexuals. Rev Bras Enferm. 2020;73(2):e20180688. doi: http://dx.doi.org/10.1590/0034-7167-2018-0688

Corresponding author:

Luís Eduardo Soares dos Santos

E-mail: luisedu.edu19@gmail.com

EDITOR IN CHIEF: Dulce Aparecida Barbosa ASSOCIATE EDITOR: Hugo Fernandes

Submission: 08-30-2018 Approval: 02-27-2019

\begin{abstract}
Objectives: To analyze the perception of male homosexuals regarding the access to the Unified Health System. Methods: A qualitative study with male homosexuals in a city in the Northeast Brazil. Eight subjects participated, a socioeconomic questionnaire was used for data collection and a focal group was carried out, in which the narratives were recorded and later transcribed. For the analysis of the speeches, the analysis of thematic content was used. Results: The analysis revealed five thematic categories that express the limitations on humanization and reception, as well as in the quality of health care offered to subjects, disregarding the psychosocial and lifestyle-related demands. Final considerations: It was emphasized that the focus group technique contributed to the approach of the research with the perception of male homosexuals marked by prejudice and discrimination, reflecting the subjects' dissatisfaction with the care received in the health services.

Descriptors: Male Homosexuality; Sexual and Gender Minorities; Public Health; Access to Health Services; Comprehensive Health Care.
\end{abstract}

\section{RESUMO}

Objetivos: Analisar a percepção de homossexuais masculinos a respeito do acesso ao Sistema Único de Saúde. Métodos: Estudo qualitativo realizado com homossexuais masculinos em uma cidade do Nordeste do Brasil. Participaram oito sujeitos, sendo utilizado para coleta de dados um questionário socioeconômico e realizado um grupo focal, no qual as narrativas foram gravadas e posteriormente transcritas. Para análise das falas empregou-se a análise de conteúdo temática. Resultados: A análise revelou cinco categorias temáticas que expressam as limitações na humanização e no acolhimento, bem como na qualidade do atendimento à saúde oferecido aos sujeitos, desconsiderando as demandas psicossociais e relacionadas ao estilo de vida. Considerações finais: Destaca-se que a técnica do grupo focal contribuiu para a aproximação da pesquisa com a percepção dos homossexuais masculinos marcada por preconceito e discriminação, refletindo a insatisfação dos sujeitos com o atendimento recebido nos serviços de saúde.

Descritores: Homossexualidade Masculina; Minorias Sexuais e de Gênero; Saúde Pública; Acesso aos Serviços de Saúde; Assistência Integral à Saúde.

\section{RESUMEN}

Objetivos: Analizar la percepción de los hombres homosexuales sobre el acceso al Sistema Único de Salud. Métodos: Un estudio cualitativo con hombres homosexuales en una ciudad en el noreste de Brasil. Participaron ocho sujetos, se utilizó un cuestionario socioeconómico para la recolección de datos y se llevó a cabo un grupo focal, en el que se registraron las narrativas y luego se transcribieron. Para el análisis de los discursos, se utilizó el análisis de contenido temático. Resultados: El análisis reveló cinco categorías temáticas que expresan las limitaciones en la humanización y la recepción, así como en la calidad de la atención médica que se ofrece a los sujetos, sin tener en cuenta las demandas psicosociales y relacionadas con el estilo de vida. Consideraciones finales: Se destacó que la técnica del grupo focal contribuyó al enfoque de la investigación con la percepción de los homosexuales masculinos marcados por el prejuicio y la discriminación, lo que refleja la insatisfacción de los sujetos con la atención recibida en los servicios de salud.

Descriptores: Homosexualidad Masculina; Minorías Sexuales y de Género; Salud Pública; Accesibilidad a los Servicios de Salud; Atención Integral de Salud. 


\section{INTRODUCTION}

The right to health is ensured by the Brazilian Constitution and implemented by the Unified Health System (SUS); however, regarding the health demands of vulnerable social groups, such as the lesbian, gay, bisexual, transvestite and transsexual population (LGBT), there are still some barriers to a society in which heteronormativity prevails(1).

The access of the LGBT population to health is marked by obstacles, such as inadequate behavior and discriminatory treatment of health professionals, which ultimately distract them from health services. The relationship between homosexuality and health has been frequently discussed in the last century and has been the subject of debates and contestations both in the medical sciences and in the social sciences ${ }^{(2)}$.

The complexity of the health situation of the LGBT community and the evidence of the influence that sexual orientation and gender identity have on the social determination of health imply the construction of integrated actions for the promotion of social inclusion, so that the access and quality health services can contribute to tackling inequities ${ }^{(3)}$.

In this context, the LGBT population may not have their health needs integrally contemplated as being subordinated to homophobia and other types of prejudice. Moreover, this group fears to reveal their sexual orientation in the health services, visualizing the negative impact that this will bring to the quality of care ${ }^{(4)}$.

In fact, the LGBT group, due to the non-adequacy of gender to biological sex or heteronormative sexual identity, has its basic human rights violated and unmet, and is often in a vulnerability scenario $^{(1)}$. It should be noted that a nation such as Brazil, which proposes in most of its governmental guidelines the promotion of social justice, must consider the differences between social groups and construct a policy of integral attention to equitable health for those who are in a situation of vulnerability.

In this sense, important advances are observed in the Brazilian context, such as the Program Brasil sem Homofobia ${ }^{(5)}$ and the Policy of Comprehensive Health Care for the LGBT Community ${ }^{(3)}$. However, this population still faces difficulties considering various forms of violence and institutional discrimination.

Thus, the LGBT group's restricted access to public health services requires urgent actions by the public power to guarantee resources and training of professionals in order to universalize the health care of male homosexuals. Thus, there is a need for consensus on the applicability of such actions in the field of sexuality that are focused on both individual and biological risks as well as on the structural and social characteristics of the most diverse population segments, especially those in a vulnerable situation.

In order to advance the quality of care to the LGBT population, it is necessary to recognize the inequities in access to health services and the discriminatory behaviors that health professionals employ in assisting these subjects. It is also necessary to value specific and singular issues faced by this group, since their health problems often emerge from the lack of effective and adequate care for their demands ${ }^{(6)}$.

Considering the previously said, this study has as its object the perception of male homosexuals about access to public health services.

\section{OBJECTIVES}

To analyze the perception of male homosexuals regarding access to the Unified Health System.

\section{METHODS}

\section{Ethical aspects}

This study was approved by the Research Ethics Committee of the School of Health Sciences of the University of Brasília (CEP/FS/UnB).

\section{Methodological reference}

In this study, a theoretical contribution was made to the content analysis technique, which presents three stages: (1) pre-analysis, (2) exploitation of the material, and (3) treatment of results, inference and interpretation. The pre-analysis is characterized by the constitution of the corpus of the research through the organization of the material to be analyzed, thus making it operational. In the exploration of the material, the corpus coding techniques are administered, which corresponds to the transformation of the raw data found in the text, which occurs by clipping, aggregation and enumeration and allows to achieve a representation of the content. The treatment of the results, the inference and the interpretation correspond to the way the findings are treated. Then the condensation of the coded data occurs, seeking information for analysis, which will result in inferential interpretations ${ }^{(7)}$.

\section{Type of study}

This is a qualitative, exploratory and descriptive study.

\section{Study Scenario}

The research was developed in the city of Picos, state of Piauí, Brazil, from July to September 2015. The place chosen for the study with the participants was the auditorium of Casa Brasil, which is a restricted, welcoming, airy and easily accessible environment.

\section{Data source}

The subjects of the research were eight male homosexuals. It was decided to use a non-probability sampling method, called snowball, because it is a strategy to locate difficult or impossible samples to find ${ }^{(8)}$.

\section{Data collection and organization}

A focal group (FG) was performed with the eight study participants, which lasted 1 hour and 25 minutes. The meeting sought to discuss the LGBT population's access to public health services and the quality of care received. Initially the study proposal was presented and the signing of the Informed Consent Term (TCLE) was requested. During the FG, the narratives were recorded and later transcribed for subsequent analysis and discussion. Sociodemographic data of the participants were also collected 
through a questionnaire containing the variables: age, education, marital status, income, race and activism in the LGBT movement.

The dynamics of the FG occurred in four moments. The first one was the opening, when the coordinators presented themselves and explained about the purpose of the research. The second moment consisted of the presentation of the participants, and they were asked to present themselves and complete the following sentence: "For me, being gay is..." In the third moment, a reflection took place, in which the participants were divided into pairs and invited to discuss among themselves about situations experienced by them in health services. Finally, at the fourth moment, a debate was initiated and given the opportunity for them to express shared experiences for all FG participants.

\section{Data analysis}

The data obtained during the FG were analyzed using the thematic content analysis technique ${ }^{(7)}$, taking as a registration unit the segment of text that contained a complete assertion about the object being studied, that is, complete sentences. Next, the log units were grouped into subcategories, which, in sequence, were grouped into the constructed categories.

\section{RESULTS}

The subjects were between 19 and 34 years old, six reported brown skin color and five declared themselves unmarried, while three lived in a stable union. Regarding religion, three cited African-based religions, two affirmed to follow Catholicism and one, Protestantism. With regard to income, six reported receiving less than one minimum wage. Three claimed to be activists in the LGBT movement.

\section{Use of the focus group technique for the development of thematic categories}

The objective of this study was to discuss the reception and access of male homosexuals through the FG technique, considering that the Policy of Comprehensive Health Care for the LGBT Community $^{(3)}$ recommends expanding the population's access to public health services and strengthening participation of representatives of the group in the deliberative agencies of SUS.

For this, a FG was held with the participants, in which they could discuss their longings for improvements in the offer of health services that contemplated their demands and respected their identity. During the activity, the subjects' speeches were recorded and, from their transcription and application of the content analysis technique, five main thematic categories emerged: (1) reception; (2) humanization; (3) the male homosexual in the health network; (4) comprehensive health care for the male homosexual; and (5) qualification of care for the LGBT population.
The analysis of the categories revealed limitations in the humanization and reception, as well as in the quality of care offered to the subjects. Health care for the LGBT population was based, according to the statements, on aspects related to the sexual health of the participants, disregarding the psychosocial and lifestyle demands. For clarity in the description of data collection and categories presented, an organizational chart was elaborated (Figure 1). 
It is important to emphasize that the subjects see the real need to have a care directed to their singularities, however, they are not there to impose privileges, because what they demand is a reformulation of the practices in the sense of obtaining effective access to health.

\section{Category 2 - Humanization}

This category portrays the subjects' perceptions about the humanization of health care for the male homosexual population. It is divided into two subcategories: equality in care and homosexual identity, and it expresses the second most representative category in the speeches of the subjects with thirteen recording units.

In the subcategory equality in care, the participants report the need to have respect and attention to their health demands. They say they do not feel respected by health professionals, who in turn do not have the sensitivity to perceive and consider the inferences of their sexuality in the process of social welfare.

I wish there was no need for this imposition of respect. That I should be respected, just like anyone else. (E3)

Because what we want is equality. This is what the movement raises the flag: for citizenship and for equality of rights. (E5)

In addition to the needs for resolving assistance, the reports allow us to identify that the fragmentation of care for this specific population can often be associated with attitudes of disrespect on the part of the professionals, a conduct that shows denial of their citizenship rights.

Still in this context, in the subcategory homosexual identity, the participants refer that prejudice and discrimination with their sexuality are a barrier to health care, because they involve institutionalized stigmas that oppress these subjects and that increase their condition of vulnerability.

The fragility. Because many homosexuals feel fragile, they think: ah, because I am gay I will not be heard. (E2)

We have a burden of prejudice, of discrimination, of social traumas. (E8)

An important aspect to be highlighted in the testimonies is the fact that the mentioned "fragility" permeates the entire health and disease process of the subjects in question, from the moment they determine a greater vulnerability to certain diseases and conditions, fear of seeking care and not being accepted, to the moment that, facing the possibility of care, it presents itself in a limited way, reinforcing traumas and prejudices once experienced, which distances them from health services.

\section{Category 3 - The male homosexual in the health network}

This category includes the services used by homosexuals and their perceptions about the integrality of care in the health network. It includes the following subcategories: the most sought out ealth service and reference and transversality in care, represented by eleven units of registry.
In the most sought out health service subcategory, participants identify the Testing and Counseling Center (CTA) as the most sought after health service and as the basis for the health care of this population, since they are always referenced for this service.

That is why we are talking about the CTA, because CTA is pretty much home to gays. Because I'm at the health clinic and, oh, look for the CTA. I'm going to Regional - go to CTA to do your HIV test. (E4)

Another problem identified in this context is the definition of a single health service as a point of support for this population, because when seeking other care they are directed to do so. This again demonstrates the process of fragmentation of care, since these individuals can perceive the need for services to work in a shared way.

Following this scenario, in the subcategory reference and transversality in care, the participants identify the need to include their demands in the health networks, expanding the actions beyond specific services, emphasizing, even, the limits of basic care for both, considering the lack of standardization.

Interconnected networks, trained professionals, they are not in the CTA, but in the health network. (E2)

I went to the CTA, I took the exam and the results were fine [...] Then, the patient is there, on the loose, and now? Who will guide me? (E5)

There is nothing, just the health agents, the token A that they ask you if the person is gay, bisexual, lesbian, transvestite, transsexual. (E6)

They identify that there is no transversality of LGBT comprehensive health care in SUS and that, in the reference process, they are always referred to the CTA. They also reiterate the need for communication between SUS and the organized social groups of the LGBT movement.

\section{Category 4 - Attention to the comprehensive health care of the male homosexual}

It includes participants' views on the resolubility of public services in the integral care of the homosexual. This category is structured from two subcategories: attendance of the specific demands and multiprofessional or interdisciplinary team, and it was composed by ten registration units.

The subcategory attendance of the specific demands brings the lack reported by the participants of basic health services that are essential for them.

We go to the CTA, there isn't a quick test. They say it's only for pregnant women, in case of emergency. (E7)

In addition to the precariousness of materials that should be available in the service indicated, in the subcategory multiprofessional or interdisciplinary team, there are testimonies about the lack of specialized professionals to meet their needs, with emphasis on psychological support.

The problem of most gay people is precisely the psychological barrier, which needed broader support from psychologists working on this issue. (E8) 
In this sense, these subjects face difficulties in a double way, since they notice the lack of material resources and, mainly, of human resources. They reiterate the need for multiprofessional care, which would bring greater care support to them.

\section{Category 5 - Qualification of service to the LGBT population}

It deals with the perceptions of homosexuals about the need to qualify health professionals to meet the specific demands of the LGBT population. This category has the lowest number of registration units, eight, and was composed of only one subcategory: professional qualification.

Here, the participants identify that there is no professional preparation that qualifies the health service to meet their demands and there is no management effort in the training of these professionals. It also includes reports that demonstrate professional behavior that often reproduces prejudice and discrimination, even in the process of improving knowledge.

What exists is the training for the professionals to attend to the general public and then, within that training, it should already insert us. (E4)

As a professional, I was part of a training on Pink October and Blue November [...] as a professional and assumed homosexual, inside, I feel ridiculed by the lack of preparation of a doctor and offended, extremely offended. (E8)

As a professional and as a user, I know that there is no capacity in the city to service for LGBT people. (E1)

There is a need for this training, for the understanding of this environment by these people, to understand these people, the prejudices, the traumas suffered. (E3)

The testimonies bring important points regarding the lack of training of health professionals and denounce that there is no positioning of the management in relation to the implementation of actions that can change this reality. It is worrying to see that health care in these services does not go through a process of reformulation in the face of the gaps in care present in the daily life of these subjects.

\section{DISCUSSION}

The results of the study show some barriers to the effective access of male homosexuals to public health services, highlighting the lack of adequate reception as one of the main problems faced. From this point of view, the act of receiving humanized care is noticed as a product of the relationships in the care process, which occurs after the access to health services has passed ${ }^{(9)}$.

The reception is a method thought and implemented to collaborate with the qualification of the health systems, in a way that allows the user the access to a fair and all-round service, aiming at listening and attending their needs ${ }^{(10)}$. To do so, it is necessary to advance the health care of the LGBT population, overcoming the ties of the health system.

The mistaken homoaffective perceptions of health professionals, for example, were pointed out as the first obstacles encountered by the homosexual when seeking care. Additionally, in a Brazilian study that evaluated the perceptions of the LGBT population about health services, $43.3 \%$ of the interviewees were discriminated against in the public health services and $30 \%$ in the private health service ${ }^{(11)}$.

In a systematic review of the literature, it was pointed out that the homosexual population has difficulties in accessing health services as a result of heteronormative attitudes imposed by professionals and that the resulting discriminatory care violates human rights in access to health ${ }^{(12)}$.

In this scenario, the invisibility of the issues of gender and sexual orientation in health practices, as well as the disregard of the ways of experiencing sexuality, stand out negatively in the health care process. In general, this type of positioning has direct implications for the health care of the LGBT population. Thus, assistance based on heteronormativity acts in conjunction with other forms of structural violence, generating a hostile, stigmatizing and segregating environment in health services ${ }^{(13)}$.

These barriers can lead the homosexual user to feel devalued and not seek the service anymore, failing to exercise a social right that is protected by law and also gives citizenship. Admittedly, there may be difficulty in declaring a sexual orientation that differs from the cisheteronormative pattern; therefore, the rights to privacy, autonomy and access to the health services of homosexual persons must be preserved and respected.

Regarding the professional/user relationship, another study showed that health professionals feel uncomfortable in providing care to patients with non-heterosexual orientation, ratifying the homoaffective perceptions reported in this research, which makes homosexual care discriminatory ${ }^{(14)}$.

The dimension of access brought by homosexuals in the humanization category is expressed as the desire for equality in care. The units of analysis that make up this category showed the existence of institutional violence with male homosexuals as an expression of the prejudices of many health professionals.

This data corroborates the results of another research carried out in the Brazilian Northeast about the perception of health professionals' care received by gays, lesbians, bisexuals and transgenders, who emphasized the constant violation of their rights in universal and equitable access to the national health system ${ }^{(15)}$.

Therefore, raising awareness among health professionals about care free of prejudices and judgments is necessary, in addition to bringing these professionals closer to national public policies and to the specific problems of the LGBT population, ensuring that the principles of universality, integrity and equity constitutive of SUS are the praxis of these professionals ${ }^{(16)}$.

The study participants' perception regarding the use of health care networks portrays the lack of services that meet the specific demands of this population and the fragility in the responses of the health system given to their needs, expressing the idea that the health of the group is restricted to sexually transmitted infections (STIs).

It was noticed that the visits received by the participants of the study were restricted to the testing and counseling center, identifying it as the basis for health care of this population, since the professional's reference is always to that place, regardless of the complaint presented by the homosexual. 
A similar result was observed in another study where the discourses on LGBT health centered on the search for health services motivated predominantly by the screening, diagnosis or treatment of STIs ${ }^{(17)}$. In this way, it is verified that, when attending this public, health professionals prioritize sexual behavior and its vulnerability to sex-related diseases, disregarding other needs presented by them, such as food, education and emotional balance.

Also, health care assistance actions are generated from the view that the need for equity is structured in the face of a vulnerability related to promiscuity with unprotected sex and to the multiplicity of partners as conduct developed by the population in question ${ }^{(18)}$.

Against this understanding, a different reality was observed in another study, once the results showed a more welcoming modeling of care by professionals with this population. Consultations, group activities and therapeutic sessions provided a harmonious way of expressing feelings and helped to deal with situations of violence, such as counseling and advising about the life with HIV/AIDS ${ }^{(19)}$.

Therefore, it is necessary to reformulate the way in which LGBT health care is done in Brazil, because all actions must permeate all areas of the health sector, including actions in primary care and specialized care, in order to offer a care free of any prejudice or discrimination and to consider all health needs, other than those related to sexual health ${ }^{(3)}$.

From the perspective of homosexuals participating in this study, there is no professional qualification to meet their demands and, often, the process of training professionals results in actions of reproduction of prejudice and discrimination. The training of professionals, therefore, should be promoted by managers and comply with the guidelines of the LGBT Policy ${ }^{(3)}$ regarding popular participation and social control in the SUS, forming social leaders and LGBT activists, integrating them into the decision-making process and organization of the provision of services in health units aiming to guarantee citizenship and human rights ${ }^{(20)}$.

Still on the perception of homosexuals in relation to the care they receive in the health units, another Brazilian research showed that $56.67 \%$ of the members of the LGBT community recognize themselves as individuals with different needs, therefore, they consider that the professionals do not know the subject enough and that they need to be less prejudiced ${ }^{(11)}$.

The participants of this research also point out the lack of trained professionals as one of the main obstacles to the resolubility of their health problems, highlighting the need for psychological support. Violence against the LGBT population is considered a stressful factor that can negatively impact the mental health and quality of life of these people, contributing to the occurrence of depressive disorders and their consequences, such as anxiety, social isolation, eating disorders and use or abuse of psychoactive substances ${ }^{(1,21)}$.

According to the national report ${ }^{(22)}$, the main form of violence directed at the LGBT population is psychological, at a total of $83.2 \%$. Thus, any sexual manifestation different from the normative system of gender is subjected to physical, sexual and/or psychological violence and can be perceived in different contexts, such as in health units ${ }^{(19)}$.

The transformations required for greater access to health services and the full recognition and promotion of the human rights of the LGBT population require changes in a system that does not provide care for non-normative identities and bodies and their needs. The effectiveness of inequality in these services occurs through the association of the choice to live a sexuality contrary to the heteronormative, showing gaps on the understanding of the real events and needs that generate the true vulnerabilities to the LGBT group. In addition, the binary and cisgender logic that guides the health system subjectively influence health care and social relations, generating situations of prejudice and discrimination ${ }^{(18,23)}$.

\section{Study limitations}

The limitation of the study is related to the singular context of the participants, not allowing the generalization of the results obtained from the analysis of the testimonies collected, being necessary studies in other scenarios.

\section{Contributions to the field of healthcare}

The study discusses issues related to the health of male homosexuals, a theme permeated by prejudice that reveals a mismatch between the principles and guidelines of SUS and the daily care practices of health care.

It reiterates the importance of discussing the structural gaps within the scope of LGBT health care. This discussion should not be considered only on the epistemological side, but also from the need to understand the real living conditions and perceptions of these subjects, since the health problems of this group are socially determined.

Therefore, the results of the study drive forward new research in the field of public health that makes it possible to unveil the reality of care to this group, within its limits and possibilities, giving foundation to the development of strategies that allow, above all, to qualify this care, to guarantee their more fundamental rights, in order to overcome the different types of violence that demarcate their existences.

\section{FINAL CONSIDERATIONS}

The results of the study show that the perception of male homosexuals about the access to SUS reveals some barriers, such as the reception marked by prejudice and discrimination, health care professionals based on the sexual orientation of users and discriminatory and excluding behaviors.

Among the categories of analysis, reception and humanization were highlighted, reflecting the subjects' dissatisfaction with the care received in health services and the desire to have their health needs fully addressed.

Another evidence of the study is the perception of the need for qualification of the health professional as a measure that is aligned with the guidelines of Brazilian legislation and that should be recommended by health managers, considering that the training of these professionals may contribute to overcoming the standardization of sexuality expressions according to the heteronormative logic.

The attitude of the professionals in the health units towards the LGBT user determines, in part, the quality of care based on the recognition of the singularity and subjectivity of each subject, as well as the ways of living and interacting in the world that do not fit the socially accepted and legitimized. Nevertheless, in the 
reality investigated, such attitudes have been markedly based on prejudices that lead professionals, in their therapeutic potential and health promoter, to propose and develop limited actions that only contribute to legitimize stereotypes regarding this public, for example what happens when they are only referred to the CTA, considered as the only possible space to meet the complex health demands on the agenda.

Given this scenario, the integral approach and the humanization of care by health professionals becomes urgent, considering that there have been reports about institutional violence against male homosexuals, as well as the lack of resolution of the service in meeting the specific demands of this population.

With the consolidation of the principles and guidelines of public LGBT health policies and the active listening of their representatives, it is expected that the distance between these users and public health services will gradually decrease so that the health sector becomes an effective partner in protecting the rights and guaranteeing the social participation of male homosexuals.

\section{REFERENCES}

1. Cardoso MR, Ferro LF. Saúde e população LGBT: demandas e especificidades em questão. Psicol Cienc Prof[Internet]. 2012 [cited 2018 Jun 20];32(3):552-63. Available from: http://www.scielo.br/pdf/pcp/v32n3/v32n3a03.pdf

2. Cesaro CGK. Políticas públicas de saúde à população LGBT: percepção das travestis que se prostituem diante da realidade da cidade de Confresa - MT. ACENO[Internet]. 2016 [cited 2018 Jul 5];3(5):223-41. Available from: http://periodicoscientificos.ufmt.br/ojs/index.php/aceno/article/view/3812/pdf

3. Ministério da Saúde (BR). Secretaria de Gestão Estratégica e Participativa. Departamento de Apoio à Gestão Participativa. Política Nacional de Saúde Integral de Lésbicas, Gays, Bissexuais, Travestis e Transexuais. Brasília: Ministério da Saúde; 2013.

4. Araújo MAL, Galvão MTG, Saraiva MMM, Albuquerque AD. Relação usuária-profissional de saúde: experiência de uma mulher homossexual em uma unidade de saúde de referência de Fortaleza. Esc Anna Nery[Internet]. 2006 [cited 2018 Feb 10];10(2):323-7. Available from: http:// www.scielo.br/pdf/ean/v10n2/a22v10n2.pdf

5. Ministério da Saúde (BR). Conselho Nacional de Combate à Discriminação. Brasil sem homofobia: programa de combate à violência e à discriminação contra GLTB e de promoção da cidadania homossexual. Brasília: Ministério da Saúde[Internet]. 2004 [cited 2018 Jun 1]. Available from: http://bvsms.saude.gov.br/bvs/publicacoes/brasil_sem_homofobia.pdf

6. Veale JF, Watson RJ, Peter T, Saewyc EM. Mental health disparities among Canadian transgender youth. J Adolesc Health[Internet]. 2017 [cited 2018 Jul 1];60(1):44-9. Available from: https://www.jahonline.org/article/S1054-139X(16)30358-5/fulltext

7. Lobiondo-Wood G, Haber J. Pesquisa em Enfermagem: métodos, avaliação crítica e utilização. Rio de Janeiro: Guanabara-Koogan; 2001.

8. Bardin L. Análise de Conteúdo. São Paulo: Edições 70; 2016

9. Silva JL. Como os serviços de saúde acolhem a população LGBT? In: II Seminário Nacional Gênero e Práticas Culturais[Internet]; 2009 [cited 2018 Aug 1]; Universidade Federal da Paraíba; João Pessoa. Available from: http://www.itaporanga.net/genero/gt8/10.pdf

10. Coutinho LRP, Barbieri AR, Santos MLM. Reception in Primary Health Care: an integrative review. Saúde Debate[Internet]. 2015 [cited 2018 Out 11];39(105):514-424. Available from: http://www.scielo.br/pdf/sdeb/v39n105/0103-1104-sdeb-39-105-00514.pdf

11. Carvalho LS, Philippi MM. Percepção de lésbicas, gays e bissexuais em relação aos serviços de saúde. Universitas: Ciênc Saúde [Internet]. 2013 [cited 2018 Mar 10];11(2):83-92. Available from: https://www.publicacoesacademicas.uniceub.br/cienciasaude/article/viewFile/1837/2286

12. Albuquerque GA, Garcia CL, Quirino GS, Alves MJH, Belém JM, Figueiredo FWS, et al. Access to health services by lesbian, gay, bisexual and transgender persons: systematic literature review. BMC Int Health Hum Rights[Internet]. 2016 [cited 2018 Jul 5];16(2):1-10. Available from: https://www.ncbi.nlm.nih.gov/pmc/articles/PMC4714514/pdf/12914_2015_Article_72.pdf

13. Ferreira BO, Edson OP, Tajra FS, Araújo ZAM, Freitas FRNN, Pedrosa JIS. Paths and experiences of the research process regarding the health of the LGBT population in a northeastern Brazilian capital. Rev Tempus[Internet]. 2017 [cited 2018 Out 11];11(1):41-49. Available from: http:// docs.bvsalud.org/biblioref/2018/03/880377/lgbt-3-ing.pdf

14. Sousa JC, Mallmann DG, Galindo Neto NM, Freitas NO, Vasconcelos EMR, Araújo EC. [Health promotion of lesbian woman: nursing care]. Rev Gaúcha Enferm[Internet]. 2014 [cited 2018 Jan 20]; 35(4):108-13. Available from: http://www.scielo.br/pdf/rgenf/v35n4/1983-1447rgenf-35-04-00108.pdf

15. Albuquerque GA, Quirino GS, Figueiredo FWS, Paiva LS, Abreu LC, Valenti VE, et al. Sexual diversity and homophobia in health care services: perceptions of homosexual and bisexual population in the cross-cultural theory. OJN[Internet]. 2016 [cited 2018 Mar 23];6(6):470-82. Available from: https://file.scirp.org/pdf/OJN_2016061316203529.pdf

16. Albuquerque GA, Garcia CL, Alves MJH, Queiroz CMHT, Adami F. Homossexualidade e o direito à saúde: um desafio para as políticas públicas de saúde no Brasil. Saúde Debate[Internet]. 2013 [cited 2018 Apr 20];37(98):516-24. Available from: http://www.scielo.br/pdf/sdeb/v37n98/ a15v37n98.pdf

17. Garcia CL, Albuquerque GA, Drezett J, Adami F. Health of sexual minorities in north-eastern Brazil: representations, behaviours and obstacles. J Hum Growth Dev[Internet]. 2016 [cited 2018 Jun 23];26(1):94-100. Available from: http://pepsic.bvsalud.org/pdf/rbcdh/ v26n1/14.pdf Portuguese

18. Oliveira GS, Nogueira JA, Costa GPO, Medeiros RLSFM, Oliveira T, Almeida SA. Health services for lesbians, gays, bisexuals and transvestites/ transexuals. Rev Enferm UFPE[Internet]. 2018 [cited 2018 Dec 22];12(10):2598-609. Available from: https://periodicos.ufpe.br/revistas/ revistaenfermagem/article/view/237014/30152 
19. Fernandes H, Oliveira EM, Ventura RN, Horta ALM, Daspett C. Violence and vulnerability to HIV/Aids in young homosexuals and bisexuals. Acta Paul Enferm[Internet]. 2017 [cited 2018 Oct 11];30(4):390-6. Available from: http://www.scielo.br/pdf/ape/v30n4/en_0103-2100ape-30-04-0390.pdf

20. Ministério da Saúde (BR). Secretaria de Gestão Estratégica e Participativa. Departamento de Apoio à Gestão Participativa. Relatório do Seminário Nacional de Saúde LGBT. Brasília: Ministério da Saúde; 2015.

21. Albuquerque GA, Parente JS, Belém JM, Garcia CL. Violência psicológica em lésbicas, gays, bissexuais, travestis e transexuais no interior do Ceará, Brasil. Saúde Debate[Internet]. 2016 [cited 2018 Mar 10];40(109):100-11. Available from: http://www.scielo.br/pdf/sdeb/ v40n109/0103-1104-sdeb-40-109-00100.pdf

22. Secretaria de Direitos Humanos (BR). Relatório sobre violência homofóbica no Brasil: ano de 2012 [Internet]. 2013 [cited 2018 Jul 1]. Available from: http://www.rcdh.es.gov.br/sites/default/files/RELATORIO\%20VIOLENCIA\%20HOMOFOBICA\%20ANO\%202012.pdf

23. Gomes R, Murta D, Facchini R, Meneghel SN. Gender and sexual rights: their implications on health and healthcare. Ciênc Saúde Coletiva[Internet]. 2018 [cited 2018 Jul 17];23(6):1997-2005. Available from: http://www.scielo.br/pdf/csc/v23n6/en_1413-8123-csc-23-06-1997.pdf 